\title{
Las pequeñas explotaciones cañeras tucumanas entre el Laudo Alvear y la política azucarera del primer peronismo
}

\author{
Small sugar planters farms in Tucuman \\ between the Laudo Alvear \\ and the first Peronism sugar policy
}

\author{
María Celia Bravo \\ Consejo Nacional de Investigaciones Científicas y Técnicas \\ Instituto Superior de Estudios Sociales \\ Universidad Nacional de Tucumán
} (Argentina) mcbravo@hotmail.com

Julieta Bustelo Consejo Nacional de Investigaciones Científicas y Técnicas Instituto Superior de Estudios Sociales Universidad Nacional de Tucumán (Argentina) julibustelo@yahoo.com.ar

\section{Resumen}

Desde sus inicios, la agroindustria azucarera tucumana se consolidó con la preponderante participación de cañeros, plantadores de caña que vendían su materia prima a los ingenios. Las relaciones entre cañeros e industriales resultaron conflictivas producto de los desacuerdos sobre el precio de la caña que marcaba la distribución del ingreso azucarero. El Laudo Alvear de 1928 fue la primera regulación que intentó normalizar las relaciones entre ambos sectores. El presente trabajo tiene por objetivo analizar la evolución de la estructura agraria cañera desde la aplicación del Laudo Alvear hasta el primer peronismo para examinar los efectos de las regulaciones azucareras en la estructura agraria cañera. Para alcanzar este objetivo se analiza la información estadística disponible (los censos cañeros de 1929, 1937 y 1945, además de los censos agropecuarios de 1947 y 1960) y la política azucarera desarrollada entre 1928 y 1955.

Palabras Clave: Estructura agraria cañera - Políticas azucareras - Laudo Alvear - Peronismo 


\begin{abstract}
Since its inception, the Tucuman sugar industry was characterized by an important role of sugar planters who sold their raw materials to the mills. Relations between cane workers and industrialists were conflictive due to the disagreements over the price of sugar cane which determined the distribution of income. The Laudo Alvear of 1928 was the first regulation that tried to normalize relations between these two sectors. This paper aims to analyze the evolution of sugar cane agricultural structure. We analyze the period from the application of the Laudo Alvear to the first Peronism. We are interested in examining the effects of the sugar cane regulations on agricultural structure. In order to achieve this objective we analyze statistical information available (censuses of cane workers of 1929, 1937 and 1945; the agricultural censuses of 1947 and 1960) and the sugar policy developed between 1928 and 1955.
\end{abstract}

Key Words: Sugar cane agricultural structure - Sugar policies - Laudo Alvear - Peronism

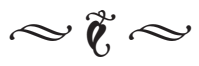

\section{Introducción}

E1 complejo agroindustrial azucarero tucumano se consolidó a fines del siglo XIX sobre la base de un medio agrario caracterizado por la presencia de la pequeña propiedad. Estos fundos se orientaron al cultivo de la caña y sus productores fueron denominados "cañeros" porque abastecían con su materia prima al parque industrial azucarero, integrado por 28 ingenios en 1948. Desde los comienzos de la actividad, cañeros e industriales habían mantenido conflictivas relaciones derivadas básicamente de las disputas por los precios de la materia prima y de las condiciones de entrega de la caña. No obstante, durante la década de 1920, los plantadores atravesaron una situación adversa generada por la crisis de la caña criolla (1916-1917) que diezmó los cañaverales. La posterior replantación de las fincas con la nueva variedad de Java fue realizada con mayor celeridad por algunos industriales, beneficiados con la mayor riqueza sacarina de la planta, que les permitió alcanzar la anhelada integración de cultivo y fabricación en una sola firma. Sin embargo, este aumento de productividad agrícola abrió una coyuntura de sobreproducción azucarera, con el consecuente descenso del precio de la caña, que afectó al sector cañero al convertir su aporte en supletorio y fortalecer la situación de los ingenios en el mercado de materia prima.

Tal situación, desató una fuerte disputa intersectorial. El año 1926 alcanzó un pico la crudeza de la crisis de sobreproducción al derrumbarse el precio de la materia prima que no logró estabilizarse en una liquidación definitiva para la zafra de ese año, y a comienzos de 1927, la situación se agravó porque los cañeros, no tenían posibilidades de colocar sus cosechas. En esa instancia, la Federación Agraria, que nucleaba la mayoría de los productores cañeros declaró la primera huelga agraria de la provincia, al anunciar que no se suministraría materia prima a los ingenios. Tal decisión exigió una aceitada logística por parte de los plantadores que lograron paralizar 
la zafra y desplegaron una activa campaña a través de nutridas manifestaciones y de petitorios con sus demandas dirigidos a los poderes públicos. Para resolver el conflicto ambas partes acordaron la mediación del presidente de la Nación que aceptó arbitrar las diferencias. Su fallo, dado a conocer en 1928, conocido como Laudo Alvear, se propuso normalizar las relaciones intersectoriales al introducir un contrato único de compraventa de materia prima. ${ }^{1}$

E1 Laudo revelaba que el Estado nacional asumía la resolución de la disputa intersectorial al concebirse equidistante de los intereses privados en pugna y recurría a una lógica científica sustentada en el estudio de la economía azucarera y en los conocimientos técnicos de los profesionales. Se trataba de establecer un criterio irrefutable, fundado en los costos productivos, con el objetivo de establecer la distribución del ingreso azucarero entre ambos sectores propietarios de la agroindustria. Para definir el principio distributivo la Secretaría Arbitral envió tres comisionados a distintas áreas productoras de azúcar (Luisiana, Java, Hawaii, Alemania, Checoeslovaquia) con la instrucción de recabar precisiones técnicas sobre este asunto, pero sobre todo, analizar las consideraciones económico-sociales de las distintas economías azucareras.

El Estado nacional supeditó el criterio distributivo a dos variables: el significado del proteccionismo y el sentido de la pequeña

1. Sobre el proceso de gestación de la protesta cañera, definición de demandas y sentidos del Laudo Alvear véase BRAVO, María Celia, Campesinos, azúcar y política: cañeros, acción corporativa y vida politica en Tucumán (1895-1930), Prohistoria Ediciones, Rosario, 2008. propiedad. ${ }^{2}$ En la primera, se asumía al proteccionismo como privilegio soportado por el pueblo argentino en tanto consumidor, valoración negativa propia de la visión liberal del radicalismo alvearista, que solo lo justificaba si se aplicaban mecanismos distributivos destinados al mejoramiento social. Tal concepción tenía implícita una jerarquización espacial que se proyectaba a los distintos emprendimientos productivos. El complejo agroindustrial tucumano, destinado al mercado interno, era considerado "artificial" por precisar de tarifas protectoras para su funcionamiento. Tal percepción sugería una suerte de "superioridad productiva" en favor de los emprendimientos pampeanos orientados al mercado externo, presentados como los emblemas exitosos del liberalismo económico. En función de este criterio, el presidente se asumió como representante de los intereses de los consumidores, sector que fue contemplado en el Laudo y que incidió en el diseño de la política azucarera.

La segunda variable tomaba en cuenta la presencia de los pequeños cañeros independientes, sector que suscitó en el árbitro una valoración positiva al considerar que la pequeña propiedad era imprescindible para fomentar el arraigo del hogar agrícola. Luego de un prolijo análisis de los costos de industrialización y de producción de la materia prima, concluía que los valores generados por el procesamiento y el cultivo de una tonelada de caña eran equivalentes, de modo que correspondía a industriales y a cañeros, la mitad del valor comercial del azúcar.

2. PODER EJECUTIVO NACIONAL (PEN), Conflicto Fabril Cañero de la Provincia de Tucumán, Laudo del Presidente de la Nación Marcelo T. de Alvear, Ministerio de Agricultura de la Nación, Buenos Aires, 1928, pp. 8-13. 
Asimismo, consideraba que el aporte del sector de productores de materia prima era necesario para el funcionamiento de los ingenios $y$ establecía un porcentaje sectorial de molienda a razón de 43,42 \% correspondiente a los cultivadores y $56,58 \%$ para los industriales.

En el presente trabajo nos proponemos analizar la evolución de la estructura agraria cañera desde la aplicación del Laudo Alvear hasta implementación de las nuevas modalidades de comercialización de la materia prima introducidas por los primeros gobiernos peronistas (1946-1955). En esa dirección, el objetivo del artículo consiste en establecer si estas nuevas políticas trataban de corregir el peso del minifundio o alentaban el fraccionamiento de la propiedad cañera. La hipótesis que preside este trabajo sostiene que el peronismo mensuró la incidencia económica negativa de la difusión de la pequeña propiedad en la actividad azucarera (situación no contemplada por el Laudo Alvear que interpretó positivamente su presencia) $\mathrm{y}$, al influjo de las recomendaciones de los técnicos del Banco Central, del Ministerio de Agricultura y de la Secretaría de Industria y Comercio, Dirección de Azúcar (DNA), identificó a la estructura agraria cañera tucumana como un problema a resolver que requería de acciones graduales que podían corregirse a largo plazo con la implementación de un nuevo régimen de comercialización de la caña y a través del desarrollo de modalidades cooperativas de producción para productores minifundistas. Este postulado justifica el corte temporal del artículo puesto que el Laudo Alvear fue el primer instrumento que instituyó la distribución sectorial de los réditos azucareros beneficiando al sector cañero. Posteriormente, las leyes provinciales reguladoras de la producción azucarera de la 66 década de 1930 profundizaron este postulado al discriminar positivamente a los campesinos minifundistas (se los eximió del cupo de producción y se les otorgó bonificaciones adicionales en la compraventa de su materia prima). Por el contrario, los decretos del peronismo, anularon tal discriminación aunque les otorgó otros beneficios. Para examinar los efectos de las políticas impulsadas por el peronismo, el artículo realiza un análisis de carácter estadístico destinado a observar los cambios y continuidades en la estructura agraria cañera. En ese sentido, analizaremos la documentación estadística censal disponible en el período: los censos cañeros de 1929, 1937 y 1945, además de los censos agropecuarios de 1947 y $1960 .{ }^{3}$ Esta información se cruzará con el análisis de la política azucarera desarrollada por los diferentes gobiernos, especialmente la implementada durante el período peronista.

Los estudios sobre la agroindustria azucarera tucumana durante los primeros gobiernos peronistas se centraron en la modernización de las relaciones laborales, en la irrupción del sindicalismo simbolizado en el accionar de Federación Obrera Tucumana de la Industria del Azúcar (FOTIA), en los diversos sentidos adoptados por la política azucarera, en el papel del crédito acordado a los industriales. ${ }^{4}$ Por su

3. No se considerarán materiales como los Anuarios Estadísticos de la Provincia de Tucumán y La Revista Industrial y Agrícola de Tucumán (editada por la Estación Experimental Agrícola de Tucumán) porque su información no es compatible para un análisis del agro cañero en el largo plazo.

4. Sobre las relaciones laborales véanse: MURMIS, Miguel y WAISMAN, Carlos, "Monoproducción agroindustrial, crisis y clase obrera, la industria azucarera tucumana", en Revista Latinoamericana de Sociología, Buenos Aires, 1969, № 1; RUBINSTEIN, Gustavo, Los sindicatos azucareros en los orígenes del peronismo tucumano, Universidad Nacional de Tucumán, San Miguel de 
parte, la problemática de la pequeña propiedad cañera ha concitado valiosos estudios que indagaron en las causas de la pervivencia de la economía campesina tucumana desde los inicios de la modernización de la agroindustria azucarera a finales del siglo XIX. Una respuesta

Tucumán, 2006. Sobre sobre la política azucarera véanse: CAMPI, Daniel, "Política azucarera argentina, 19451990: regulación y crisis” (inédito). Versión castellana de ponencia presentada en The International Sugar Economy in the Post-War World: 1945-90, Universidad de East Anglia, Norwich, 1990; CAMPI, Daniel y KINDGARD, Adriana, "La política azucarera argentina en las décadas de 1920 y 1930 y la cuestión de la 'justicia distributiva"', ponencia presentada en III Congreso Brasileiro de Historia Económica, Curitiba, 1999; BRAVO, María Celia, "Disputas sectoriales, agrarismo cañero y regulaciones en la industria azucarera tucumana en la década de 1930", en ASCOLANI, Adrián y OLIVERA, Gabriela (compiladores) Corporaciones y movimientos sociales agrarios en Argentina (1912-2008), UNR, Rosario, 2014; BRAVO, María Celia y GUTIÉRREZ, Florencia, "La política azucarera argentina: de la concertación sectorial al tutelaje estatal (1928-1945)", en Revista H-industri@, Buenos Aires, 2014, No 14, pp. 153-185.

Sobre créditos a los industriales azucareros véanse: GIRBAL-BLACHA, Noemí, "Cooperativismo agrario y crédito oficial (1946-1955). Una aproximación a las continuidades y cambios de la Argentina peronista", en Anuario del Centro de Estudios Históricos "Prof. Carlos S. A. Segreti”, Córdoba, 2001, Año 1, № 1. Disponible en: <http://www.cehsegreti.com.ar/archivos/ FILE_00000252_1310740130.pdf>; GIRBALBLACHA, Noemí, "Economía azucarera tucumana, empresarios y crédito en tiempos del Estado peronista (1946-1955)", en MACOR, Darío y TCACH, César (editores) La invención del peronismo en el interior del país, Universidad Nacional del Litoral, Santa Fe, 2003; GIRBAL-BLACHA, Noemí, "El Estado benefactor, dirigista y planificador. Continuidad y cambio en la economía y la sociedad argentina", en GIRBALBLACHA, Noemí, ZARRILLI, Adrián y BALSA, Javier, Estado, sociedad y economía en la Argentina (19301997), Universidad Nacional de Quilmes, Bernal, 2004 pp. 69-108; GIRBAL-BLACHA, Noemí: "El crédito oficial al agro y a las industrias tradicionales. Estudio de casos", en GIRBAL-BLACHA, Noemí, Mitos, paradojas y realidades en la Argentina peronista (1046-1955), Universidad Nacional de Quilmes, Bernal, 2011. ofrecida por Jorge Balán enfatizó la resistencia exitosa a la proletarización de los pequeños productores de orientación comercial que se volcaron a la producción cañera. Por su parte, Roberto Pucci retomó una vía, ya señalada por Emilio Schleh, para explicar la formación del sector cañero, el declive de los trapiches domésticos cuyos fundos se dedicaron de manera exclusiva al cultivo de la caña, además de las pequeñas propiedades rurales que se orientaron al mismo cultivo en función de los altos precios. No obstante, Carlos León sostiene que no se verificó la reconversión de la economía campesina hacia la caña de azúcar y que el minifundio azucarero actuó fundamentalmente como proveedora de fuerza de trabajo a los minifundios azucareros. María Celia Bravo afirma que el pequeño productor agrario se dedicó al cultivo de la caña incentivado por los altos precios y estimulados por las facilidades brindadas por los ingenios a partir de 1890. En las primeras décadas del siglo XX su participación en el área sembrada creció, aunque con altibajos, hasta alcanzar en 1928 el 43,42\%, porcentaje estipulado en el Laudo Alvear. ${ }^{5}$ La producción de trabajos que analizan la década de 1930 es menor, podemos mencionar las contribuciones de la misma autora quien analizó los efectos de las

5. BALÁN, Jorge, "Migraciones, mano de obra y formación de un proletariado rural en Tucumán, Argentina, 1870-1914", en Demografía y economia, México, 1976, V.X, No 29; SCHLEH, Emilio, La industria azucarera en su primer centenario, 1821-1921, Ferrari, Buenos Aires, 1921. PUCCI, Roberto, "La élite azucarera y la formación del sector cañero en Tucumán (1880-1920)", en Conflictos y Procesos de la Historia Argentina Contemporánea CEAL, Buenos Aires, 1989, № 37. LEÓN, Carlos, "El desarrollo agrario de Tucumán en el período de la transición de la economía de capitalismo incipiente a la expansión azucarera", en Desarrollo Económico, Buenos Aires, 1993, V. XXXIII, No 130. BRAVO, María Celia, Campesinos, azúcar y política..., Op. Cit. 
leyes reguladoras en la producción azucarera tucumana, específicamente en el sector cañero. ${ }^{6}$ Para el período relativo a los primeros gobiernos peronistas, los estudios relativos a la situación de los cañeros son aún menores, lo cual requiere de nuevas investigaciones que revisen esa problemática tan poco explorada. En este sentido, podemos destacar la tesis doctoral de Julieta Bustelo referida a los clivajes de la política azucarera en clave cañera durante la década peronista. ${ }^{7}$

\section{Información sobre la documentación estadística a utilizar}

Es pertinente realizar una breve descripción de los censos a utilizar a fin de determinar la información que brinda cada uno. Los datos

6. BRAVO, María Celia, "Regulaciones en la Industria Azucarera Argentina, Estado, Cañeros e Industriales, 1928-1938", en VIEIRA, Alberto (compilador) Historia do açúcar. Fiscalidade, Metrologia, Vida Material e Património, Centro de Estúdos do Atlántico, Funchal, 2006; BRAVO, María Celia, “Disputas...”, Op. Cit.; BRAVO, María Celia y GUTIÉRREZ, Florencia, "La política azucarera...”, Op. Cit.

7. BUSTELO, Julieta, Asociacionismo cañero tucumano y politica azucarera durante el primer peronismo Tesis Doctoral, Universidad Nacional de Tucumán, 2015. Otros trabajos de esta autora que abordan el medio agrario cañero y las políticas azucareras en el período peronista son: BUSTELO, Julieta, "Las políticas azucareras durante el primer peronismo (1943-1955): cambios, continuidades y respuestas sectoriales", en Travesía, San Miguel de Tucumán, 2015, V. XVII, No2; BUSTELO, Julieta, "Hacia una caracterización de la estructura agraria cañera de Tucumán en los inicios del primer peronismo", en Revista del Departamento de Geografía, San Miguel de Tucumán, 2013-2014, № 14, pp. 9-28; BUSTELO, Julieta, "El nuevo asociacionismo de los cañeros tucumanos en los orígenes del peronismo: la formación de la Unión de Cañeros Independientes de Tucumán”, en Mundo agrario. Revista de estudios sociales, La Plata, 2012, V.XIII, No 25. Disponible en: <http:// mundoagrarioold.fahce.unlp.edu.ar> censales de 1929 son extraídos de un número de la Revista Azucarera que reproduce la información recabada por la Cámara Gremial de Productores de Azúcar. Esta institución gubernamental llevaba una contabilización detallada de la cantidad de fincas, extensión cultivada y producción obtenida, conla finalidad de calcular los porcentajes sectoriales de producción y la bonificación que correspondía a cada productor. El Censo Nacional de las Plantaciones de Caña de Azúcar fue levantado en 1937 y publicado en 1938 como parte del Censo General Agropecuario de 1937, realizados ambos por la Comisión Nacional del Censo General Agropecuario (CNCGA), dependiente del Ministerio de Agricultura de la Nación. En abril de 1945 se realizó un nuevo Censo de las Plantaciones de Caña de Azúcar que fue publicado en agosto del mismo año. Éste formaba parte del IV Censo General de la Nación, aunque el de caña fue realizado y publicado unos años antes. Asimismo, se realizó en cumplimiento del decreto 648/45 del 13 de enero de $1945,{ }^{8}$ que ordenaba a la Dirección Nacional de Censos y Estadística (DNCE) levantar un censo nacional de las plantaciones de caña tanto de cañeros independientes como de ingenios.

El Censo Agropecuario de 1947 formó parte del IV Censo General de la Nación del mismo año, realizado por la Dirección Nacional de Investigaciones, Estadística y Censos (DNIEC) y publicado recién en 1955 . En relación con el cultivo de caña de azúcar, éste no utilizó los datos del censo de 1945

8. Este decreto fue elaborado por la Comisión Nacional Investigadora de la Industria Azucarera que se conformó a mediados de julio de 1943, al poco tiempo de la asunción del Gral. Ramírez, y que tenía como objetivo estudiar la industria azucarera a nivel nacional para darle una nueva organización y regulación. 
que -como ya se señaló- formaba parte del IV Censo General, sino que recabó nuevamente esa información. Uno de los principales objetivos del IV Censo era contabilizar población y recursos del país en pos de obtener datos para terminar de diseñar e implementar el Primer Plan Quinquenal. ${ }^{9}$ Por último, el Censo Agropecuario de 1960 que fue parte del Censo Nacional del mismo año, realizados ambos por la Dirección Nacional de Estadística y Censos (DNEC) y publicados en 1964. Aunque haya sido realizado en una etapa posterior al período peronista, consideramos que nos permitirá contrastar algunas hipótesis referidas a la evolución de la estructura agraria cañera.

De esta forma, teniendo en cuenta la disparidad de los datos en los censos que disponemos, la información sobre el universo cañero a lo largo de los dos gobiernos peronistas no será equitativa. El censo cañero de 1945 contiene información nacional, por provincia y por departamentos, respecto del número de las explotaciones cañeras, diferenciándolas por superficie, por producción, por escala de extensión de las explotaciones, y por fundos de cañeros independientes y de ingenios. Con estos datos pormenorizados podremos reconstruir con cierto grado de precisión la estructura agraria cañera en los inicios del

9. Hacía treinta y tres años que no se realizaba un Censo General de la Nación, esta demora era producto de la oposición de varias provincias, ya que el recuento de población provincializaría a varios territorios nacionales y consecuentemente modificaría la composición del Poder Legislativo Nacional. Frente a la inexistencia cercana de una experiencia censal de tal envergadura, el Censo de las Plantaciones de Caña de 1945 ofició a nivel regional como la experiencia más reciente. Véase GONZÁLEZ BOLLO, Hernán, "La Dirección Nacional de Investigaciones, Estadística y Censos y el estado peronista (1946-1949)", en Estudos e pesquisas, Salvador, 2011, No 90, pp. 205-223. peronismo. El censo cañero de 1937 contiene información bastante similar a la de 1945, por lo cual el análisis contrapuesto de ambos censos nos permitirá arribar a conclusiones sobre la modificación de la estructura agraria cañera previa al peronismo. Mientras que los censos agropecuarios de 1947 y 1960 otorgan una información bastante detallada del agro argentino, en cuanto a escala de las explotaciones, régimen de tenencia de la tierra y tipo de producciones registrado a nivel nacional, provincial y departamental. No obstante, no proporciona datos relativos a la escala de extensión de las explotaciones de caña de azúcar, de las que solo registra cantidad de fincas y superficie.

En consecuencia, sobre la base de la información disponible de los distintos censos podremos estudiar cómo se modificaron a lo largo del peronismo el número de explotaciones rurales y la evolución de su superficie para obtener una aproximación sobre la fragmentación de las fincas cañeras a partir de los datos sobre escala de extensión de las explotaciones agropecuarias por departamento. Asimismo, como contamos con información estadísticas de algunos años del peronismo sobre la proporción de molienda de caña de cañeros y de ingenios de los diferentes ingenios en determinadas zafras, podremos deducir la participación de los cañeros independientes e ingenios dentro del complejo azucarero tucumano.

\section{Los fundos cañeros en la etapa previa al peronismo}

La década de 1930 es en varios sentidos interesante para analizar la estructura del 
campo cañero. En primer lugar, porque en esta etapa las distintas organizaciones cañeras lograron imponer una interpretación del Laudo Alvear que diera prioridad a las pequeñas explotaciones. En segundo lugar, porque la difusión de la pequeña propiedad cañera dejó de ser considerada una panacea o punto de llegada de la agroindustria tucumana y comenzó a ser visualizada como una arista problemática y conflictiva de la actividad azucarera.

Las leyes de regulación azucarera votadas por la legislatura provincial en 1928, 1932 y 1937 cuyas normas rigieron hasta 1941 asumieron explícitamente la defensa del pequeño productor al implementar mecanismos impositivos destinados a desalentar a los ingenios a moler sus propios cañaverales y, por el contrario, promovieron la compra de materia prima de cañeros independientes, respetando el porcentaje de reducción fijado por ley, que recortaba el $30 \%$ de la producción cañera. ${ }^{10}$ Asimismo, se estipulaba que los cañeros con cosechas de $10 \frac{1}{2} 2$ toneladas -correspondiente a fundos cuya superficie era menor a 1 hectárea (ha) - no estaban contemplados en la reducción y debía molerse la totalidad de su cosecha. Por último, se establecía que el precio promedio de la comercialización del azúcar (usado como base para calcular el valor de la materia prima) debía fijarse desvinculado de las pérdidas ocasionadas por la exportación. ${ }^{11}$

La normativa reguladora no mitigó las

10. SCHLEH, Emilio, Compilación Legal sobre el Azúcar. Legislación de Tucumán, T. IV, Ferrari, Buenos Aires, 1939. En este volumen se transcribe el texto de las distintas leyes y fragmentos de los debates legislativos que las mismas generaron.

11. Para obtener más información sobre este punto, véase BRAVO, María Celia, “Regulaciones...”. Op. Cit. turbulencias sociales protagonizadas por las organizaciones cañeras durante la década de 1930. Las protestas derivaron en huelgas de distinto voltaje que tenían el propósito de rechazar el precio promedio del azúcar en el mercado interno definido por la Cámara Gremial de Productores. Esta institución creada por el gobierno tucumano surgió al influjo de la gran huelga cañera de 1927 para resolver mediante un Tribunal Arbitral las disputas sectoriales generadas por la interpretación de los contratos de compraventa de materia prima. Posteriormente, incorporó otras funciones derivadas del Laudo Alvear como la fijación del precio promedio de los $10 \mathrm{~kg}$. de azúcar granulado en la plaza de Buenos Aires, valor de referencia que fijaba las cotizaciones de la materia prima.

Con el correr de los años, a medida que aumentaron las existencias de azúcar, el precio promedio del azúcar granulado tendió a bajar, circunstancia que exasperó a las organizaciones de plantadores que rechazaron con firmeza los precios de la caña surgidos de la aplicación de la fórmula establecida por el Laudo Alvear. Los dirigentes cañeros sostenían que el valor obtenido bajo ese procedimiento no alcanzaba a cubrir los costos de producción, por lo tanto, exigieron la fijación de un precio teórico para establecer el monto de la tonelada de materia prima. Esta designación aludía a la definición de un valor, que debía desvincularse de las leyes de mercado para obtener una mayor apreciación de la materia prima con el objetivo de cubrir los gastos de la explotación, además de un beneficio. El fundamento de la demanda se centraba en la acusación a los industriales por el manejo "irresponsable" de las ventas en el mercado interno debido a la premura por vender para cubrir sus compromisos económicos, ese comportamiento afectaba 
Cuadro 1. Precios establecidos sobre la base de los $10 \mathrm{Kg}$ de azúcar granulado en la plaza de Buenos Aires, 1929-1934. Elaboración propia.

\begin{tabular}{|c|c|c|c|c|}
\hline \multirow[b]{2}{*}{ Años } & \multicolumn{2}{|c|}{ Cámara Gremial de Productores } & \multirow{2}{*}{$\begin{array}{l}\text { Precio teórico } \\
\text { demandado por } \\
\text { los cañeros }\end{array}$} & \multirow{2}{*}{$\begin{array}{l}\text { Transferencia del sector } \\
\text { industrial al sector cañero }\end{array}$} \\
\hline & $\begin{array}{l}\text { Precio } \\
\text { fijado }\end{array}$ & Precio autorizado & & \\
\hline 1929 & $\$ 2,78$ & $\begin{array}{l}\text { Se reconoció } \$ 3,30 \text { a los } \\
\text { fundos de } 0 \text { a } 8 \text { has (aporte } \\
\text { de un fondo del gobierno). } \\
\$ 3,05 \text { a los restantes } \\
\text { productores }\end{array}$ & $\$ 3,30$ & $\begin{array}{l}\$ 1.101 .133 \text { para fundos } \\
\text { de más de } 10 \text { has, más } \\
\$ 480.000 \text { aportados por } \\
\text { el gobierno para fincas de } \\
0 \text { a } 8 \text { has }\end{array}$ \\
\hline 1930 & $\$ 2,66$ & $\begin{array}{l}\$ 3 \text { Se reconoció } \$ 3,30 \text { a los } \\
\text { fundos de } 0 \text { a } 8 \text { has }\end{array}$ & --- & $\begin{array}{l}\$ 2.008 .108 \text {. Se repite el } \\
\text { monto de } \$ 480.000 \text { a } \\
\text { cañeros chicos }\end{array}$ \\
\hline 1931 & $\$ 3,15$ & $\$ 3,32$ & $\$ 3,30$ & $\$ 890.017$ \\
\hline 1932 & $\$ 3,08$ & $\$ 3,32$ & $\$ 3,32$ & $\$ 1.627 .884$ \\
\hline 1933 & \multicolumn{3}{|c|}{ Acefalía de Cámara Gremial. Se repite precio } & $\$ 183.601$ \\
\hline 1934 & \multicolumn{3}{|c|}{ Cámara Gremial fija $\$ 3,32$} & $\$ 326.939$ \\
\hline
\end{tabular}

Fuente: SCHLEH, Emilio, Compilación legal sobre el azúcar, T. VIII, Ferrari, Buenos Aires, 1943, p. 124.

a los plantadores y desordenaba el mercado doméstico del azúcar.

El cuadro 1 refleja la diferencia entre los precios del azúcar definidos por la Cámara Gremial de Productores según la lógica del mercado y los efectivamente oficializados por el gobierno para aplacar las protestas cañeras. Como puede observarse, el máximo precio del azúcar alcanzado por los cañeros se logró en 1931, valor que se mantuvo hasta 1940 cuando los cañeros se declararon en huelga para que se reconociera el mismo valor a la materia prima sin derechos. ${ }^{12}$ Las cifras de la última columna constituyen un valor estimativo de la transferencia de ingresos del sector industrial al agrario, resultado que se obtiene de deducir la diferencia entre ambos precios aplicándola a la producción de azúcar producida por cañeros.

El cuadro revela, en números, el tenor de la derrota económica experimentada por los industriales durante la década de 1930. En

12. Se denominaba materia prima sin derecho a la cosecha derivada de las nuevas plantaciones realizadas por plantadores pero que no había sido oficializadas por la Cámara Gremial de Productores. 
efecto, el respaldo presidencial al discurso agrarista (instituido por el Laudo Alvear) otorgó legitimidad a las reivindicaciones de las organizaciones cañeras y restó fuerza a las argumentaciones de los industriales que sostenían que el precio teórico encarecía los costos de producción al pagarse la materia prima molida como si se hubiese vendido el azúcar, que en realidad pasaba a engrosar el stock debido a las condiciones de saturación del mercado, situación que dificultaba el movimiento financiero de las fábricas. Como contrapartida, se intensificó la movilización de los plantadores que disputaron anualmente el precio teórico del azúcar, superior al del mercado, que ante la presión cañera era autorizado finalmente por la Cámara Gremial de Productores ante la amenaza de huelga.
En consecuencia, la Cámara naufragó en su intento de canalizar y descomprimir las tensiones intersectoriales. El rol moderador fue desempeñado por el gobernador de Tucumán a través de distintos arbitrajes y por el presidente Castillo que asumió dicha función en 1941 para evitar una nueva huelga cañera. En consecuencia, las distintas asociaciones cañeras disputaron exitosamente los beneficios azucareros al sector industrial, como se observa en el cuadro 1 y se manifestó también en el crecimiento del número de plantadores independientes y en la mayor participación de este sector en el medio agrario como puede observarse en el cuadro 2.

El presente cuadro nos permite sacar conclusiones sobre la evolución de las

Cuadro 2. Escala de explotaciones (expl.) de cañeros, Tucumán 1929-1945. Elaboración propia.

\begin{tabular}{lccccccccc}
\hline & \multicolumn{2}{c}{1929} & & 1937 & $1929-1937$ & 1945 & $1937-1945$ \\
\cline { 2 - 9 } $\begin{array}{l}\text { Escala en hectáreas } \\
\text { (has) }\end{array}$ & Expl. & $\%$ & Expl. & $\%$ & $\begin{array}{c}\text { Diferencia de } \\
\text { crecimiento de } \\
\text { expl. }\end{array}$ & Expl. & $\%$ & $\begin{array}{c}\text { Diferencia de } \\
\text { crecimiento } \\
\text { de expl. }\end{array}$ \\
\hline 0 a 5 has & 4.674 & 77 & 11.871 & 81 & 7.197 & 14.471 & 76 & 2.600 \\
\hline más de 5 a 10 has & 547 & 9 & 1.519 & 10 & 972 & 2.734 & 14,5 & 1.215 \\
\hline más de 10 a 20 has & 425 & 7 & 709 & 5 & 284 & 1.001 & 5,5 & 292 \\
más de 20 a 100 has & 365 & 6 & 405 & 3 & 40 & 686 & 3,5 & 281 \\
más de 100 has & 61 & 1 & 186 & 1 & 125 & 85 & 0,5 & -101 \\
Totales & 6.072 & 100 & 14.690 & 100 & 8.618 & 18.977 & 100 & 4.287 \\
\hline
\end{tabular}

Fuentes: CAA, Revista La Industria Azucarera, No. 440, CAA, Buenos Aires, junio 1930, p. 327; CNCGA, Censo General Agropecuario de 1937. "Las plantaciones de caña de azúcar", Ministerio de Agricultura de la Nación, Buenos Aires, 1938; CNEC, Censo de las Plantaciones de Caña de Azúcar de 1945, Informe No 1 y No 2, Ministerio del Interior, Buenos Aires, 1945. 
plantaciones entre 1929 y 1945 y detectar los segmentos cañeros que experimentaron mayor crecimiento. Con respecto a la primera premisa, el cuadro 2 muestra el destacado aumento de la cantidad de fundos cañeros, de 6.072 en 1929 a 14.690 en 1937 y a 18.977 en 1945 , incorporando un $142 \%$ de productores en 1937 y un $29,1 \%$ en 1945 . Dentro del total de explotaciones, en 1937 el segmento de 0 a 5 has se incrementó con 7.197 nuevas explotaciones y su presencia dentro del sector cañero aumentó del 77 al 81 \%. En 1945 las explotaciones de hasta 5 has se incrementaron en 2.600 unidades, pero su presencia en el conjunto del sector cañero descendió de 81 $\%$ en 1937 a $76 \%$ en 1945. De modo que, las explotaciones minifundistas (que eran una característica de la estructura agraria tucumana), tendieron a crecer y consolidarse en 1937, pero experimentaron un declive en su participación global durante el lapso 19371945.

La información que consideramos más relevante es la caída pronunciada de las explotaciones de 10 a 20 has, cuya participación disminuye desde un $7 \%$ en 1929 a un $5 \%$ en 1937, para elevarse al 5,5 \% en 1945. Un declive similar experimenta el segmento de 20 a 100 has, de $6 \%$ en 1929 a $3 \%$ en 1937 , aumentando a 3,5\% en 1945. Las unidades mayores de 100 has tienden mantenerse estables durante todo el período. De modo que, las regulaciones aplicadas en la primera mitad de la década de 1930 estimularon el crecimiento de todos los segmentos cañeros, pero especialmente de los pequeños productores de 0 a 10 has cuya presencia alcanza su pico en 1937 cuando expresan al 91,1\% del medio cañero, porcentaje que disminuye levemente en 1945 hasta representar el 90,6\% de los productores azucareros. Resta destacar precisiones en torno a la pequeña propiedad. Podemos diferenciar a las explotaciones de 0 a 5 has, consideradas unidades antieconómicas, parvifundios que no podían asegurar la reproducción de la familia campesina, aún con el aumento del precio teórico y los beneficios acordados por las organizaciones agrarias. La franja de 5 a 10 has integran también el universo de la pequeña propiedad y su explotación aportaba un exiguo beneficio que no le permitía una vida decorosa.

\section{El Informe reservado del Banco Central} consideraba que en el año 1945 una explotación económica viable debía tener como mínimo una extensión de 20 has (1000 surcos) y afirmaban que esa unidad "bien trabajada, con abonos y rendimientos de $700 \mathrm{Kg}$ de caña por surco, o sea 700 toneladas en total, puede dejar una ganancia retributiva". ${ }^{13}$ Este segmento aludía explotaciones que consideramos medianas, $(20$ a 100 has), rango amplio, que debe ubicarse en el contexto de un medio cañero cuya estructura agraria había sufrido una profunda fragmentación, en tanto expresaban solo el 4 $\%$ del total en 1945 . El peso de las grandes fincas, por encima de las 100 has era ínfimo al representar solo el 1,5 de la estructura cañera en 1945.

Ahora bien, si centramos nuestro análisis en los fundos minifundistas afloran diferencias en este segmento productivo, las que revelan la complejidad del universo cañero. $\mathrm{Al}$ respecto, los datos del Centro Azucarero Argentino (CAA) de 1937 difieren levemente con los resultados del Censo Nacional de las Plantaciones de Caña de 1937, pero vamos a remitirnos a los primeros datos para explorar la composición del pequeño cañero. Del cuadro 3

13. BCRA, Informe General de la Comisión Interministerial de Asuntos Azucareros del Banco Central de la República Argentina, BCRA, Buenos Aires, 1949, p. 7. 
Cuadro 3. Explotaciones de caña según extensión y superficie cultivada, Tucumán 1937. Elaboración propia.

\begin{tabular}{lrrrr}
\hline Escala en hectáreas & Explotaciones & \% & Hectáreas & \% \\
\hline 0 a 1 ha & 2.838 & 21 & 1.830 & 6 \\
más de 1 a 4 has & 7.771 & 59 & 16.659 & 49 \\
más 4 a 10 has & 2.644 & 20 & 15.315 & 45 \\
Totales & 13.253 & 100 & 33.804 & 100 \\
\hline
\end{tabular}

Fuente: CAA, Estadística Azucarera, No 7, Buenos Aires, 1937, p. 10.

se desprende que la figura típica de campesino minifundista remitía al propietario de 1 a 4 has que laboraba personalmente su campo ayudado por los miembros de su familia.

El censo de 1945 avanza en la exploración del universo de las pequeñas fincas y conviene incorporarlo al análisis porque aunque adopta una clasificación diferente según superficie, nos permite compararlas con el cuadro 3. Si nos remitimos al cuadro 4 los fundos de 0,5 ha, sumados con el segmento de hasta 1 ha representaban 3.100 productores, 262 más que en 1937. A su vez, el segmento de 1 a 4 has en 1945 registraba 10.334 productores, que implicaba la incorporación de 2.563 nuevos cañeros respecto de 1937, incremento que se atenuaba con el descenso en 6 puntos de su porcentaje de participación en el conjunto del sector cañero (81\% en 1937 al $75 \%$ en 1945). Estos datos revelan el proceso de fragmentación de la propiedad en el segmento de pequeños productores de 0 a 4 has, que dibujaba un poseedor de plantaciones cañeras de escasa productividad, lo que demuestra que la multiplicación de las explotaciones minifundistas fueron producto de incentivos generados por la política estatal, que las eximía de limitaciones productivas. En consecuencia, el cañero "chico" logró mantener un peso real y simbólico en el medio agrario tucumano debido, no solo a su difusión sino también a su utilización, puesto que las organizaciones agrarias invocaron este segmento para designar al conjunto del sector, estrategia que potenció la capacidad de movilización de los

Cuadro 4. Escala de explotaciones de caña de 0,5 a 4 has, Tucumán 1945. Elaboración propia.

\begin{tabular}{lrr}
\hline Escala en hectáreas & Explotaciones & \% \\
\hline 0 a 0,5 ha & 683 & 5 \\
más de $\mathbf{0 , 5}$ a $\mathbf{1}$ has & 2.417 & 18 \\
más de $\mathbf{1}$ a 2 has & 4.898 & 37 \\
más de 2 a 3 has & 3.002 & 22 \\
más de 3 a 4 has & 2.434 & 18 \\
Total & 13.434 & 100 \\
\hline
\end{tabular}

Fuente: CNEC, Censo de las Plantaciones de Caña de Azúcar de 1945, Informe No 1 y No 2, Ministerio del Interior, Buenos Aires, 1945. 
"chicos" para mejorar en su favor las políticas provinciales referidas al precio del azúcar y de la materia prima.

Por otra parte, los censos de 1937 y 1945 permiten estudiar la evolución de las plantaciones de caña en los diferentes departamentos, y a partir del promedio de hectáreas por explotación, ensayar hipótesis sobre los distritos en los que tuvo mayor incidencia la pequeña explotación.
El cuadro 5 revela que en 1945 , cuatro departamentos mantenían la primacía en lo relativo a la cantidad de plantaciones cañeras: Monteros que ya ocupaba el primer lugar en 1937, aumenta 1.258 nuevas fincas en 1945 , con un promedio de 5,6 has por explotación, resultados ilustrativos del peso de la pequeña propiedad en la zona. Le sigue Cruz Alta, epicentro de la agroindustria por el número de ingenios asentados en el departamento y por la importante presencia de los cañaverales

Cuadro 5. Evolución de las plantaciones de caña de azúcar por departamentos, Tucumán 1937-1945. Elaboración propia.

\begin{tabular}{lrrrrrrrrr}
\hline \multirow{2}{*}{$\begin{array}{c}\text { Tucumán } \\
\text { Departamentos }\end{array}$} & \multicolumn{3}{c}{ Censo 1937 } & \multicolumn{3}{c}{ Censo 1945 } & \multicolumn{3}{c}{$\begin{array}{c}\text { Diferencia } \\
\text { 1937-1945 }\end{array}$} \\
\cline { 2 - 9 } & Expl. & Has & $\begin{array}{c}\text { Has por } \\
\text { expl. }\end{array}$ & Expl. & Has & $\begin{array}{c}\text { Ha por } \\
\text { expl. }\end{array}$ & Expl. & Has \\
\hline Burruyacú & 193 & 3.769 & 19,5 & 407 & 10.497 & 25,7 & 214 & 6.728 \\
Capital & 299 & 6.650 & 22,2 & 280 & 6.685 & 23,8 & -19 & 35 \\
Cruz Alta & 3.035 & 43.312 & 14,2 & 3.214 & 49.065 & 15,2 & 179 & 5.753 \\
Chicligasta & 1.942 & 12.159 & 6,2 & 2.736 & 18.195 & 6,6 & 794 & 6.036 \\
Famaillá & 1.539 & 25.457 & 16,5 & 1.867 & 31.898 & 17 & 328 & 6.441 \\
Graneros & 284 & 1.561 & 5,4 & 652 & 4.589 & 7 & 368 & 3.028 \\
Leales & 1.558 & 7.037 & 4,5 & 2.690 & 16.894 & 6,2 & 1.132 & 9.857 \\
Monteros & 4.365 & 20.616 & 4,7 & 5.623 & 31.634 & 5,6 & 1.258 & 11.018 \\
Rín Chico & 1.277 & 18.211 & 14,2 & 1.723 & 24.745 & 14,3 & 446 & 6.534 \\
Tafi & 198 & 4.244 & 21,4 & 154 & 4.134 & 26,8 & -44 & -110 \\
Trancas & - & - & - & 1 & 67 & 67 & 1 & 67 \\
Total & 14.690 & 143.016 & 9,7 & 19.347 & 198.403 & 10,2 & 4.657 & 55.387 \\
\hline
\end{tabular}

Fuente: CNCGA, Censo General Agropecuario de 1937. "Las plantaciones de caña de azúcar", Ministerio de Agricultura de la Nación, Buenos Aires, 1938; CNEC, Censo de las Plantaciones de Caña de Azúcar de 1945, Informe No 1 y No 2, Ministerio del Interior, Buenos Aires, 1945. 
pertenecientes a los ingenios, situación que se manifestaba en el alto promedio de finca por hectárea. Por el contrario, Chicligasta ocupaba el tercer lugar en lo relativo al número de explotaciones, con una presencia mayoritaria de pequeñas fincas que arrojaba un promedio por hectárea similar a Monteros. Famaillá ostentaba una alta participación de las fincas de los ingenios, resultando una composición semejante a Cruz Alta. Otro rasgo destacable es el incremento del número de fincas y de la superficie cultivada en el departamento de Burrucayú, situación que alude a un emprendimiento realizado exclusivamente por los cañeros independientes (ver cuadro 6), similar trayectoria desarrollan Graneros y Leales donde las plantaciones avanzan sobre zonas marginales que no tenían una destacable tradición cañera. En ambos casos, la expansión agraria descansa sobre los productores independientes, situación que induce a analizar el grado de concentración de las propiedades de los ingenios y determinar las áreas donde tuvieron incidencia los pequeños productores.

Este nuevo cuadro nos muestra que las plantaciones de cañeros independientes predominan por sobre las de ingenios en todos

Cuadro 6. Plantaciones de ingenios y cañeros por departamento y promedio de hectáreas por plantación, Tucumán 1945. Elaboración propia.

\begin{tabular}{lrrrrrrrr}
\hline \multirow{2}{*}{$\begin{array}{c}\text { Tucumán } \\
\text { Departamentos }\end{array}$} & \multicolumn{3}{c}{ Explotaciones } & \multicolumn{3}{c}{ Hectáreas } & \multicolumn{3}{c}{ Has por explotación } \\
\cline { 2 - 9 } & Cañeros & Ingenios & Total & Cañeros & Ingenios & Total & Cañeros & Ingenios \\
\hline Burruyacú & 399 & 8 & 407 & 7.582 & 2.916 & 10.498 & 19 & 364 \\
Capital & 251 & 29 & 280 & 3.576 & 3.109 & 6.685 & 14 & 107 \\
Cruz Alta & 3.122 & 92 & 3.214 & 17.898 & 31.167 & 49.065 & 6 & 339 \\
Chicligasta & 2.690 & 46 & 2.736 & 13.218 & 4.977 & 18.195 & 5 & 108 \\
Famaillá & 1.795 & 72 & 1.867 & 12.225 & 19.673 & 31.898 & 7 & 273 \\
Graneros & 651 & 1 & 652 & 4.581 & 8 & 4.589 & 7 & 8 \\
Leales & 2.672 & 18 & 2.690 & 14.524 & 2.371 & 16.895 & 5 & 132 \\
Monteros & 5.563 & 60 & 5.623 & 24.059 & 7.574 & 31.633 & 4 & 126 \\
Río Chico & 1.696 & 27 & 1.723 & 16.025 & 8.719 & 24.744 & 9 & 323 \\
Tafín & 137 & 17 & 154 & 1.292 & 2.842 & 4.134 & 9 & 167 \\
Trancas & 1 & - & 1 & 67 & - & 67 & 67 & - \\
Total & 18.977 & 370 & 19.347 & 115.047 & 83.356 & 198.403 & 6 & 225 \\
\hline
\end{tabular}

Fuente: CNEC, Censo de las Plantaciones de Caña de Azúcar de 1945, Informe No 1 y No 2, Ministerio del Interior, Buenos Aires, 1945. 
los departamentos de la provincia. Por otra parte, el promedio de hectáreas por plantación vuelve a corroborar la difundida presencia de fincas pequeñas entre los plantadores independientes y de grandes entre los ingenios. Asimismo, de este cuadro podemos extraer información sobre la superficie de las plantaciones. Al respecto, el censo de 1945 nos muestra que sobre el total de 198.403 has plantadas con caña, 115.047 está repartida entre 18.977 plantaciones de cañeros independientes y 83.356 has está repartida entre 370 explotaciones de ingenios, relación que revelaba mayores niveles de concentración entre las empresas fabriles. Asimismo, el porcentaje sectorial de la superficie plantada con caña se dividía de la siguiente manera: $58 \%$ para los cañeros independientes y $42 \%$ para los ingenios. Estos indicadores reflejan el notable retroceso de los ingenios en el control del área sembrada, puesto que los porcentajes sectoriales establecidos por el Laudo Alvear de 1928 estaban invertidos. La relación en favor de los plantadores se refleja en casi todos los departamentos de la provincia, salvo en Cruz Alta y Famaillá, donde la superficie de los cañaverales de ingenio supera al perímetro cultivado por los plantadores independientes. En el resto de los distritos se manifiesta la extendida presencia de los productores cañeros, cuya superioridad numérica tuvo un peso decisivo en la disputa con los ingenios por la distribución de la renta agraria y en el abastecimiento de materia prima para el procesamiento fabril. Este dato vuelve a demostrar la primacía de la concentración de la tierra entre las explotaciones de ingenios, apreciación que también queda reflejada en el mapa 1 (ver Anexo) donde se realiza la ubicación por departamento de las instalaciones fabriles. Las explotaciones de ingenios se sitúan en el departamento donde se encontraba la fábrica y en los departamentos vecinos, por ello se observa en tales distritos un mayor porcentaje de hectáreas por explotación.

\section{Evolución de los fundos cañeros y políticas azucareras durante el peronismo}

En 1945 el gobierno de facto decidió formar la Junta Nacional del Azúcar (JNA) con el objetivo de proporcionar una solución de alcance nacional a los problemas de la industria azucarera argentina, proyectando la áspera puja distributiva que se desarrollaba desde el ámbito provincial al plano nacional. En ese marco, se formó una Comisión Investigadora de la Industria Azucarera para actualizar los costos de producción, elaboración y comercialización del azúcar, cuyos resultados servirían de referencia para regular el ingreso del azúcar en el mercado doméstico y para establecer la rentabilidad de industriales y cañeros. La composición de la comisión investigadora siguió una lógica corporativa al constituirse con un integrante del Centro Azucarero Regional (CAR) que representaba a los industriales tucumanos y dos por las asociaciones cañeras existentes en la provincia, el Centro Cañero y 1a Unión Agraria Provincial. ${ }^{14}$ Los resultados del informe gestaron el decreto 678, del 13 de enero de 1945 , que cambiaría sustancialmente los parámetros de funcionamiento $\mathrm{y}$ de distribución de los beneficios azucareros. ${ }^{15}$

14. La incorporación del representante de los industriales no se concretó porque el CAR consideró que los fines de la comisión se desnaturalizaron al incorporar a sus objetivos el estudio de las condiciones de trabajo que no estaba contemplado originariamente en el decreto. SCHLEH, Emilio, Compilación legal sobre el azúcar, T. XI, Ferrari, Buenos Aires, 1947, p. 12.

\section{PEN, Decreto 678. Se da solución permanente al}


El decreto anunciaba la creación de la JNA, institución destinada a ordenar todas las fases involucradas en la actividad azucarera nacional, desde el estadio de la producción hasta la comercialización, aspecto novedoso porque en las décadas precedentes las regulaciones se implementaron a través de leyes provinciales. Tal definición anunciaba el avance estatal de impronta reguladora en el estadio de la producción agrícola-industrial y en el mundo laboral, al incorporarse por primera vez a los trabajadores como actores de pleno derecho a la puja distributiva. Con este decreto el Estado se colocaba en el centro de la escena al asumir la difícil función de asignar a cada sector retribuciones equitativas. Se establecía además un precio máximo del azúcar de $\$ 4,50$ los $10 \mathrm{Kg}$ de azúcar granulado en la plaza de Buenos Aires y se aprobaba una contribución obligatoria de \$0,06 para formar un Fondo Especial de Compensación y Asistencia Social impuesta a ingenios, importadores, comerciantes mayoristas, minoristas y refinerías. El dinero recaudado se destinaría a compensar a cañeros e industriales por mayores costos debido al incremento de los insumos y de los salarios.

En líneas generales, el decreto mantenía los lineamientos del Laudo Alvear en cuanto la forma de fijar el precio de la materia prima en relación al peso y a las condiciones de entrega de ésta. Al mismo tiempo, para los plantadores el decreto recuperaba la tradición de la década de 1930 al fijar para las zafras de 1943-1945 precios diferenciales para la materia prima (que descendían a medida que crecía la capacidad productiva de las fincas) y determinaba la liquidación total de la caña según precios máximos y mínimos de $\$ 16,50$ y $\$ 14,50$ la

problema azucarero, Buenos Aires, 1945. tonelada respectivamente. A los industriales se les reconocían compensaciones por costos de industrialización, por las crecientes obligaciones salariales derivadas de la política del gobierno y por la molienda de materia prima de los productores independientes. En este último caso, se autorizaron compensaciones a los ingenios que industrializaran un porcentaje de caña de terceros no menor al $20 \%$ de la molienda total de la fábrica y se fijaba una suma inferior cuando descendía este porcentaje. Otra novedad que incluyó el decreto 678 fue el incremento de salarios a partir del reconocimiento de una variedad de oficios y de tareas solicitadas por FOTIA en un petitorio en agosto de 1944. Se establecieron 62 especialidades de fábrica en un espacio hasta ese entonces dominado por la genérica categoría de peón y se incursionó en diferenciar las distintas tareas agrícolas, fijándose 50 para el cultivo y la cosecha, al tiempo que se elevaba el valor de cada una de estas actividades. En consecuencia, el decreto supuso una operación novedosa al jerarquizar y complejizar el trabajo en la industria azucarera. ${ }^{16}$

Las asociaciones cañeras (la Unión Agraria Provincial y el Centro Cañero) rechazaron los precios diferenciados según capacidad productiva establecida por el decreto 678, solicitaron una compensación única de $\$ 2,50$ por tonelada para todos los productores y $\$ 20$ por tonelada de caña alegando que no cubría los gastos productivos. La demanda cañera se desplazó al interior del Estado nacional, ya no se trataba de una confrontación entre cañeros y dueños de ingenios, sino de un conflicto entre estos últimos y el gobierno,

16. Sobre el incremento de las especialidades de fábrica durante el período peronista véase BRAVO, María Celia y GUTIÉRREZ, Florencia, "La política azucarera...", Op. Cit. 
en tanto las compensaciones exigidas solo podían ser fijadas por el Estado nacional. En consecuencia, el Centro Cañero y la Unión Agraria Provincial decidieron la paralización de tareas por la imposibilidad económica de iniciar la zafra. Paralelamente impulsaron gestiones para la fusión de las distintas agrupaciones cañeras y eligieron un Consejo Directivo pro-unidad del gremio que debía centralizar las negociaciones con el Estado. El gobierno nacional ofreció tres resoluciones que fueron recibidas satisfactoriamente por el gremio y, en consecuencia, se levantó la huelga. Las mismas consistieron en que la Secretaría de Industria y Comercio de la Nación giraría inmediatamente el pago de las compensaciones por las cosechas de 1943 y 1944 al precio que fijaba el decreto 678/45. En segundo lugar, para la zafra de 1944 aún impaga se estableció que el precio promedio fijado en $\$ 3,182$ los $10 \mathrm{Kg}$ de azúcar se elevaría a $\$ 3,284$-que era el precio promedio establecido para la zafra de 1943- y que los ingenios debían abonar la mitad del precio de venta de la melaza producida con esa caña. En tercer lugar, se fijó un precio provisorio para la zafra de 1945 de $\$ 16,50$, en vez de $\$ 14,50$ la tonelada de caña y un anticipo de $\$ 2,50$ por tonelada en concepto de compensación fija en el momento de la entrega de la caña. ${ }^{17}$

La aplicación del decreto 678 con estas modificaciones no significó el cese de la puja distributiva entre los sectores productivos implicados en la actividad azucarera:

17. En septiembre de 1945, las asociaciones cañeras que componían el consejo pro unidad (Unión Agraria Provincial, Centro Cañero y Cañeros Independientes) se fusionaron para conformar la Unión de Cañeros Independientes de Tucumán (UCIT). Al respecto, véase BUSTELO, Julieta, "El nuevo asociacionismo...”, Op. Cit. industriales, cañeros y obreros. En cada zafra volvieron a repetirse las demandas obreras de aumento de salarios y los consecuentes reclamos de cañeros e industriales en pos del aumento del precio de la caña y de su industrialización, de las compensaciones y de créditos para afrontar los nuevos costos. E1 gobierno, frente a estas coyunturas, mostró un buen grado de flexibilidad, que se manifestó en la profundización de la política de mediación intersectorial y en la modificación de las regulaciones azucareras contemplando los reclamos de las partes. Así, hasta el año 1949 el decreto 678 fue prorrogado con pequeñas modificaciones correspondientes a los nuevos costos. ${ }^{18}$ Hasta el año 1948 inclusive, el precio de los $10 \mathrm{Kg}$ de azúcar granulado mayorista se mantuvo fijo, pero el valor de la tonelada de la materia prima se incrementó un $146 \%$ en cuatro años, acompañando el aumento de los insumos y los salarios. Los mayores costos fueron cubiertos por el Banco

18. Para un análisis de los que prorrogaron en cada zafra al decreto 678/45 véanse: PEN, Decretos 14.584/45 y 4/4/7/995 Dto. Ado. 77/1 del 2/7/1945, reproducidos en La Industria Azucarera, Buenos Aires, julio 1945, Año LI, No 621, CAA, pp. 394-396; PEN, Decreto 19.276 del 23/8/1945, reproducido en La Industria Azucarera, Buenos Aires, septiembre 1945, Año LI, No 623, CAA, pp. 545; PEN, Decreto 27.496 del 2/11/1945, reproducido en La Industria Azucarera, Buenos Aires, noviembre 1945, Año LI, No 625, CAA, pp. 666; PEN, Decreto 16.163 del 29/5/1946, reproducido en Revista La Industria Azucarera, Buenos Aires, mayo 1946, Año LII, No 631, CAA, pp. 215-220; PEN, Decreto 1.287 del 22/6/1946, reproducido en Revista La Industria Azucarera, Buenos Aires, junio 1946, Año LII, No 632, CAA, pp. 271-275; PEN, Decreto 21.361 del 17/7/1948, reproducido en Revista La Industria Azucarera, Buenos Aires, julio 1948, Año LIV, No 657, CAA, pp. 270; PEN, Decreto 2.895 del 4/2/1949, reproducido en Revista $L a$ Industria Azucarera, Buenos Aires, febrero 1949, Año LIV, No 664, CAA, pp. 548-559; PEN, Decreto 14.209 del 18/6/1949, reproducido en Revista La Industria Azucarera, Buenos Aires, junio 1949, Año LV, No 668, CAA, pp. 16. 
Nación que otorgó compensaciones con los recursos generados por el Fondo, las que se incrementaron en el caso de la materia prima hasta cubrir el $48 \%$ del valor de la misma. ${ }^{19}$

La JNA no llegó a formarse y sus funciones fueron ejercidas por el Banco Central de la República Argentina (BCRA) hasta que en junio de 1949 se creó la DNA dependiente del Ministerio de Industria y Comercio. La formación de la nueva entidad reflejaba un giro de la función reguladora del Estado en materia de política azucarera, en ese año la entidad resolvió un abrupto incremento del precio del azúcar (138 \% de aumento) con el objetivo de liberar paulatinamente al Estado del peso de las compensaciones. Se trataba de sustentar el funcionamiento de la actividad en el precio de venta del producto, cuyo valor sería fijado sobre la base de un promedio de los costos de las distintas zonas productivas, más una utilidad ponderada. Se configuró así un esquema que contemplaba a los productores de mayor costo, pero avanzaba hacia la adopción de un criterio científico, al abandonar paulatinamente la costumbre de pesar la materia prima como indicador único y uniforme del precio de la caña. En lo sucesivo, se aplicó un sistema mixto que disminuía gradualmente el porcentaje del precio pagado según el peso y aumentaba la participación del que se pagaba según riqueza sacarina. La institución sostenía que el procedimiento más racional para la comercialización de la materia prima debía ser

19. En 1948 se alcanzó el mejor de la materia prima, \$ 32, 10 la tonelada de caña, pero ningún ingenio "abona el total del precio fijado sino un $48 \%$ del mismo, según sean los fletes, o ya sea caña propia o comprada, con riqueza sacarina superior o inferior al $77 \%$, la diferencia hasta el \$32, 10 la abona el Estado”. BCRA, Informe General de la Comisión Interministerial de Asuntos Azucareros del Banco Central de la República Argentina, BCRA, Buenos Aires, 1949, p. 21.

80 el que abonara íntegramente la planta según su riqueza en azúcar, aunque aceptaba una fase de transición para la aplicación de este sistema. ${ }^{20}$

Desde la zafra 1951, la DNA aplicó un plan de racionalización del transporte de la caña dentro de Tucumán que dio lugar a una distribución de la entrega de la materia prima ajustada a la zona de influencia de cada ingenio. Esta modalidad de venta había sido resistida en 1936 por las organizaciones agrarias que defendían el libre mercado cañero como esquema comercializador, pero el gobierno peronista impuso su criterio invocando razones de economía: se evitaba el recorrido de amplios trayectos y el consiguiente deterioro de la planta. Por otra parte, como un aspecto fundamental dentro del proceso racionalizador, en octubre de 1949, el gobierno nacional decidió la intervención de la CGT en la FOTIA en rechazo a una prolongada huelga obrera que reclamaba por la dilatación en el tratamiento y aplicación del petitorio único elevado por la entidad. Esta intervención limitó el poder de presión obrera, lo que redundó en una estabilización de los costos azucareros en términos salariales. ${ }^{21}$

20. PEN, Decreto 24.572, reproducido en Revista $L a$ Industria Azucarera, Buenos Aires, octubre de 1949, Año LV, No 672, CAA, pp. 122-124.

21. En agosto de 1948 la FOTIA había presentado este petitorio ante el CAR y la UCIT. Sus puntos más destacables consistieron en la solicitud de aumento del $50 \%$ de salarios de todos los obreros azucareros con retroactividad al $1^{\circ}$ de mayo de 1948, el incremento del salario familiar en $\$ 20$ por hijo y la obligación de veintidós días de trabajo por mes durante la época de reparaciones y cultivos y de veintiséis días como mínimo durante la época de zafra. En cuanto a las mejoras sociales, reclamaban la construcción de viviendas adecuadas, instalación de servicios de agua corriente, beneficios de jubilación y ampliación de la asistencia social. 
La DNA mantuvo una buena cuota de flexibilidad ante los reclamos de cañeros e industriales sobre la modificación del plan de transporte y de los precios mixtos de la caña y su industrialización. Esta política se volvió más rígida a partir de 1953 cuando la racionalización azucarera se enmarcó dentro de los preceptos racionalizadores fijados por el Segundo Plan Quinquenal. Éste proponía el incremento de producción de azúcar sobre la base de una mejor eficiencia en el cultivo y en la industrialización. Así, preveía la limitación del cultivo en zonas consideradas marginales por estar afectadas por accidentes climáticos y establecía el financiamiento estatal para el reequipamiento de las industrias existentes y el desarrollo de nuevas. ${ }^{22}$ Siguiendo estos lineamientos, la DNA detectó zonas marginales para el cultivo de la caña, el este del departamento de Burruyacú y parajes como Simoca recibieron esta clasificación. Para los "cañeros chicos" propuso como solución la formación de cooperativas y la mecanización agraria con el objetivo de alcanzar una zafra más corta y económica. Otro factor destacable fue la recomendación a los ingenios de poseer por lo menos el $25 \%$ de caña propia, este requisito se juzgaba necesario para la regulación equilibrada de sus propias moliendas, criterio inverso al del Laudo Alvear que había considerado al plantador independiente como un factor necesario en la economía azucarera tucumana. Al mismo tiempo, estableció que desde la zafra 1954 en adelante disminuiría progresivamente en un $75 \%$ el precio básico fijado para la caña y su industrialización, hasta alcanzar un $70 \%$ en 1955 , un $62,50 \%$ en 1956 ,

22. PEN, Segundo Plan Quinquenal, reproducido en Revista La Industria Azucarera, Buenos Aires, diciembre 1952, Año LXIII, No 710, CAA, p. 295. un $52,50 \%$ en 1957 , un $37,50 \%$ en 1958 , un $18,75 \%$ en $1959 \mathrm{y}$ el total en $1960 .^{23}$

La evolución del número de explotaciones y de la superficie cultivada con caña de azúcar durante el ciclo peronista se plasmaron en el siguiente cuadro que computa los resultados de dos censos agropecuarios: 1947 y 1960.

El dato más saliente es el descenso en el número de explotaciones, de 19.347 unidades productivas a 13.829 en 1960, una caída del $40 \%$ en quince años, cuyo declive más pronunciado se refleja en el censo de 1947, específicamente en los departamentos de Monteros (-2.734), Cruz Alta (-1.525), Leales (-1.258), Chicligasta (-1.080), Famaillá (-978), Río Chico (-765) y Graneros (-385). Las explotaciones de caña descienden pero se observa un crecimiento en la cantidad de hectáreas por explotación lo que indica un movimiento tendiente a la reconfiguración de la pequeña propiedad y un declive del parvifundio durante el ciclo peronista. Los datos son congruentes con el aumento del número de hectáreas por explotación entre 1945 y 1960 que se verifica en los departamentos donde estaba más difundida la pequeña propiedad. Así, Monteros pasa de 5,6 has en 1945 , a 8,5 has en 1947, para subir a 11 has en 1960. Leales sigue una trayectoria similar: de 6,2 has en 1945, a 8,9 has en 1947, a 9,4 has en 1960. Chicligasta muestra este mismo movimiento: de 6,6 has en 1945, 9,6 has en 1947 y 10,8 has en 1960 . Siguiendo una tendencia semejante, el aumento del promedio de hectáreas por explotación se verifica también a nivel provincial de 10,2 has en 1945 , a 15,4 has en 1947 y 15,9 en 1960. Tal información

23. Dirección de Azúcar, Resolución 127, reproducida en Revista La Industria Azucarera, , Buenos Aires, octubre 1954, Año LX, No 732, CAA, pp. 413-422. 
Cuadro 7. Evolución de las plantaciones de caña, Tucumán 1945, 1947 y 1960. Elaboración propia.

\begin{tabular}{|c|c|c|c|c|c|c|c|c|c|c|c|c|c|}
\hline \multirow{2}{*}{$\begin{array}{c}\text { Tucumán } \\
\text { Departa- } \\
\text { mentos }\end{array}$} & \multicolumn{3}{|c|}{ Censo 1945} & \multicolumn{3}{|c|}{ Censo 1947} & \multicolumn{2}{|c|}{$\begin{array}{l}\text { Diferencia } \\
1945-1947\end{array}$} & \multicolumn{3}{|c|}{ Censo 1960} & \multicolumn{2}{|c|}{$\begin{array}{l}\text { Diferencia } \\
1947-1960\end{array}$} \\
\hline & Expl. & Has & $\begin{array}{c}\text { Ha por } \\
\text { expl. }\end{array}$ & Expl. & Has & $\begin{array}{c}\text { Has por } \\
\text { expl. }\end{array}$ & Expl. & Has & Expl. & Has & $\begin{array}{c}\text { Has por } \\
\text { expl. }\end{array}$ & Expl. & Has \\
\hline Burruyacú & 407 & 10.497 & 25,7 & 313 & 8.700 & 27,7 & -94 & -1.797 & 974 & 23.647 & 24,2 & 661 & 14.947 \\
\hline Capital & 280 & 6.685 & 23,8 & 143 & 4.304 & 30 & -137 & -2.381 & 185 & 6.268 & 33,8 & 42 & 1.964 \\
\hline Cruz Alta & 3.214 & 49.065 & 15,2 & 1.689 & 38.657 & 22,8 & -1.525 & -10.408 & 1.944 & 38.742 & 19,9 & 255 & 85 \\
\hline Chicligasta & 2.736 & 18.195 & 6,6 & 1.656 & 16.016 & 9,6 & -1.080 & -2.179 & 2.130 & 23.181 & 10,8 & 474 & 7.165 \\
\hline Famaillá & 1.867 & 31.898 & 17 & 889 & 29.879 & 33,6 & -978 & -2.019 & 1.160 & 31.397 & 27 & 271 & 1.518 \\
\hline Graneros & 652 & 4.589 & 7 & 267 & 2.663 & 9,9 & -385 & -1.926 & 629 & 5.218 & 8,2 & 362 & 2.555 \\
\hline Leales & 2.690 & 16.894 & 6,2 & 1.432 & 12.780 & 8,9 & -1.258 & -4.114 & 2.033 & 19.263 & 9,4 & 601 & 6.483 \\
\hline Monteros & 5.623 & 31.634 & 5,6 & 2.889 & 24.692 & 8,5 & -2.734 & -6.942 & 3.212 & 35.448 & 11 & 323 & 10.756 \\
\hline Río Chico & 1.723 & 24.745 & 14,3 & 958 & 19.009 & 19,8 & -765 & -5.736 & 1.493 & 28.093 & 18,8 & 535 & 9.084 \\
\hline Tafí & 154 & 4.134 & 26,8 & 79 & 2.194 & 27,7 & -75 & -1.940 & 68 & 2.966 & 43,6 & -11 & 772 \\
\hline Trancas & 1 & 67 & 67 & 1 & 64 & 64 & 0 & -3 & 1 & 22 & 22 & 0 & -42 \\
\hline Total & 19.347 & 198.403 & 10,2 & 10.316 & 158.958 & 15,4 & -9.031 & -39.445 & 13.829 & 214.245 & 15,9 & 3.513 & 55.287 \\
\hline
\end{tabular}

Fuente: CNEC, Censo de las Plantaciones de Caña de Azúcar de 1945, Informe No 1 y No 2, Ministerio del Interior, Buenos Aires, 1945; DNIEC, Censo Agropecuario de 1947, IV Censo General de la Nación, T. II, Dirección Nacional del Servicio Estadístico, Ministerio de Asuntos Técnicos, Buenos Aires, 1955; DNEC, Censo Nacional Agropecuario de 1960, Secretaría de Estado de Hacienda, Dirección Nacional de Investigaciones, Estadística y Censos, Buenos Aires, 1964. 
revela que el gobierno no pudo cumplir con su propósito de limitar el cultivo en las áreas marginales puesto que se verifica la presencia e incremento de cañaverales en departamentos considerados zonas marginales y no aptos para el cultivo de la caña.

E1 Censo Agropecuario de 1960 no contiene información relativa a la participación de las explotaciones de industriales y cañeros en el cultivo de la caña de azúcar, para acercarnos a ese porcentaje utilizaremos las cuotas de molienda por zona y por sector (cosecha de industriales y de cañeros) en la molienda de la zafra de 1955.

En 1945, los cañeros habían aventajado a los industriales en el control del área sembrada con caña, puesto que, ocupaban el $57 \%$ de la superficie total, mientras que el $43 \%$ le correspondía a los cañaverales de los ingenios. En 1955, la hegemonía de los productores independientes era aplastante. Una de las áreas donde se estableció una relación sectorial más pareja fue la zona 2 donde funcionaban los ingenios Amalia, Bella Vista, Mercedes, San

Cuadro 8. Cuotas de molienda por zonas (en toneladas), Tucumán 1955. Elaboración propia.

\begin{tabular}{lrrrrr}
\hline Zonas & Caña Propia & $\%$ & Caña Comprada & $\%$ & Total \\
\hline Zona 1 & 547.000 & 23 & 1.844 .000 & 77 & 2.391 .000 \\
Zona 2 & 699.000 & 50 & 709.000 & 50 & 1.408 .000 \\
Zona 3 & 204.000 & 31 & 462.000 & 69 & 666.000 \\
Zona 4 & 103.000 & 13 & 672.000 & 87 & 775.000 \\
Zona 5 & 82.000 & 9 & 783.000 & 91 & 865.000 \\
Zona 6 & 126.000 & 25 & 374.000 & 75 & 500.000 \\
Total & 1.761 .000 & 27 & 4.844 .000 & 73 & 6.605 .000 \\
\hline
\end{tabular}

Referencias: Zona 1: Ingenios Concepción, Cruz Alta, Esperanza, La Florida, Lastenia, Leales, Los Ralos, San Antonio, San Juan (Departamentos Cruz Alta, Leales), .Zona 2: Ingenios Amalia, Bella Vista, Mercedes, San José, San Pablo (Departamento Famaillá), .Zona 3: Ingenios La Fronterita, Nueva Baviera, Santa Lucía (Departamento Famaillá), .Zona 4: Ingenios La Providencia, Nuñorco, San Ramón, Santa Rosa (Departamento Monteros), .Zona 5: Ingenios Aguilares, La Corona, La Trinidad, Santa Bárbara (Dep. Chicligasta y Río Chico), .Zona 6: Ingenios Eva Perón, Marapa (Departamento Río Chico).

Fuente: Revista La Industria Azucarera, CAA, Buenos Aires, Agosto 1955, No 742, p. 237. 
José, San Pablo (Departamento Famaillá), mientras que en las restantes zonas el aporte de la caña comprada estaba por encima del $70 \%$. Las cuotas administradas por la DNA reflejaban el peso decisivo de los cañeros en Chicligasta, Río Chico, Monteros, Cruz Alta.

\section{Conclusión}

Las políticas reguladoras de la década de 1930 promovieron la excesiva fragmentación de las explotaciones cañeras e incrementaron el número de productores. Se gestó así una estructura agraria cañera signada por la disparidad distributiva, puesto que en 1937 el $91 \%$ del total de los cañeros laboraban pequeñas fincas ( 0 a 10 has) que representaba el $25 \%$ del total de la superficie cultivada. Dentro de este grupo se destacaba el segmento de 1 a 4 has, cuyos productores eran denominados "cañeros chicos” y que constituían la expresión productiva más generalizada de la campaña tucumana, cuya presencia se encontraba en la mayoría de los departamentos azucareros, especialmente en Monteros, Chicligasta y en áreas marginales como Leales y Graneros.

Los resultados del censo de 1945 reflejaban el pico de crecimiento de los productores cañeros, cuyo número decrece levemente en 1960, mientras que la superficie cultivada sigue un curso inverso al incrementarse un 7 \% entre 1945-1960. La revolución de junio de 1943 trajo aparejada novedades en la política azucarera. A partir del decreto 678 de 1945 el Estado nacional asumió integralmente el control de la actividad al definir su funcionamiento y rentabilidad, $\mathrm{y}$ al transformar radicalmente las condiciones de trabajo en la fábrica y en el surco. En esa dirección, los cañeros interpelaron anualmente al Estado para actualizar el precio de la materia prima y cubrir el incremento de los costos derivados de los insumos y de las mejoras laborales, al tiempo que demandaban la modificación de los porcentajes sectoriales de molienda establecidos por el Laudo Alvear.

En 1949, el Estado produjo una revisión de la política azucarera al adoptar como premisa la eficiencia productiva. En esa dirección, decidió abandonar gradualmente el criterio de pagar el precio de la caña según el peso de la planta, por considerar que esa modalidad promovía el cultivo rutinario y el desinterés del agricultor para introducir nuevas variedades. En consecuencia, promovió un nuevo precio definido por la riqueza sacarina, cuyo porcentaje en el precio de la planta se incrementaría en forma paulatina. Bajo esa misma lógica, se desaconsejó el cultivo en áreas marginales y se promovió la formación de cooperativas de producción como solución al incremento de los costos generados por los cañeros "chicos". El impacto de esta política se observó en la disminución del número de explotaciones, que afectaron especialmente a los parvifundos, explotaciones minúsculas y antieconómicas como emprendimiento productivo.

La desaparición de fincas no significó un retroceso productivo. Los resultados del censo de 1947 revelan el crecimiento del número de hectáreas por agricultor, cuyo leve aumento se mantiene en 1960. Sin embargo, existen otros indicadores que revelan el notable retroceso experimentado por los ingenios tucumanos durante el peronismo. Los porcentajes de molienda decididos por la DNA en 1955 reflejan el acusado predominio del productor independiente en el cultivo de la caña en la mayoría de las zonas azucareras en las 
que se distribuye la molienda, por su parte, los ingenios mantuvieron una presencia importante solo en el área de Famaillá, pero experimentaron un notable reflujo en Cruz Alta, principal área azucarera de la provincia. De modo que, el peronismo continuó con la política de respaldo del sector cañero, al que secundó en todos sus rangos al otorgarle compensaciones por mayores costos y al autorizar anualmente el incremento del precio de la materia prima. Hacia 1950, el gobierno reformuló la política azucarera al introducir el componente de racionalidad económica y científica en lo relativo al precio de la materia prima, a las formas de cultivo y a la entrega de la cosecha, con el objetivo de modificar las aristas más improductivas del universo cañero tucumano.

El gobierno procuró que los segmentos más pequeños se acomodaran a la política de racionalización al impulsar nuevas condiciones de compraventa de materia prima destinadas a modificar de manera paulatina la fraccionada estructura agraria cañera, consolidada en la década de 1930 por legislaciones reguladoras de la producción azucarera. Desde esa perspectiva, las políticas peronistas dedicadas al sector cañero tucumano adoptaron las estipulaciones del Laudo Alvear, que especificaban las condiciones de comercialización de la caña, al tiempo que aplicaron parcialmente sus recomendaciones de avanzar hacia un sistema de compraventa fundado en el análisis sacarino a realizarse en la materia prima entregada por los productores. En esa dirección, procuraron ordenar el mercado cañero delimitando zonas marginales de cultivo y estableciendo -a modo de transición- un sistema mixto de venta de la materia prima que incorporaba el análisis de la riqueza sacarina y mantenía la modalidad de venta según el peso de la caña. Las transformaciones e indicaciones realizadas por los técnicos reflejaban además una visión del complejo industrial tucumano, que requería de ingenios propietarios de cañaverales para cubrir al menos el $25 \%$ de su molienda, condición que permitía un diseño más eficiente de la zafra. El resultado de tales políticas se reflejó en el avance del sector cañero en el área sembrada, aunque se revirtió parcialmente un factor conflictivo de la estructura cañera, el parvifundio, al disminuir drásticamente el número de fincas, caída que no se reflejó en la disminución del área cultivada, que por el contrario aumentó. Esta situación evidencia un proceso de reconfiguración de la pequeña propiedad, cuya extensión promedio se incrementó como lo corrobora el Censo de 1960.

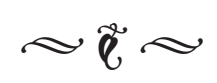

Recibido: 08 - 05 - 2015

Aceptado: 19 - 10 - 2015

Publicado: 30 - 06 - 2016 


\section{Anexo}

Mapa 1: Ingenios de Tucumán por departamentos, 1945. Elaboración propia.

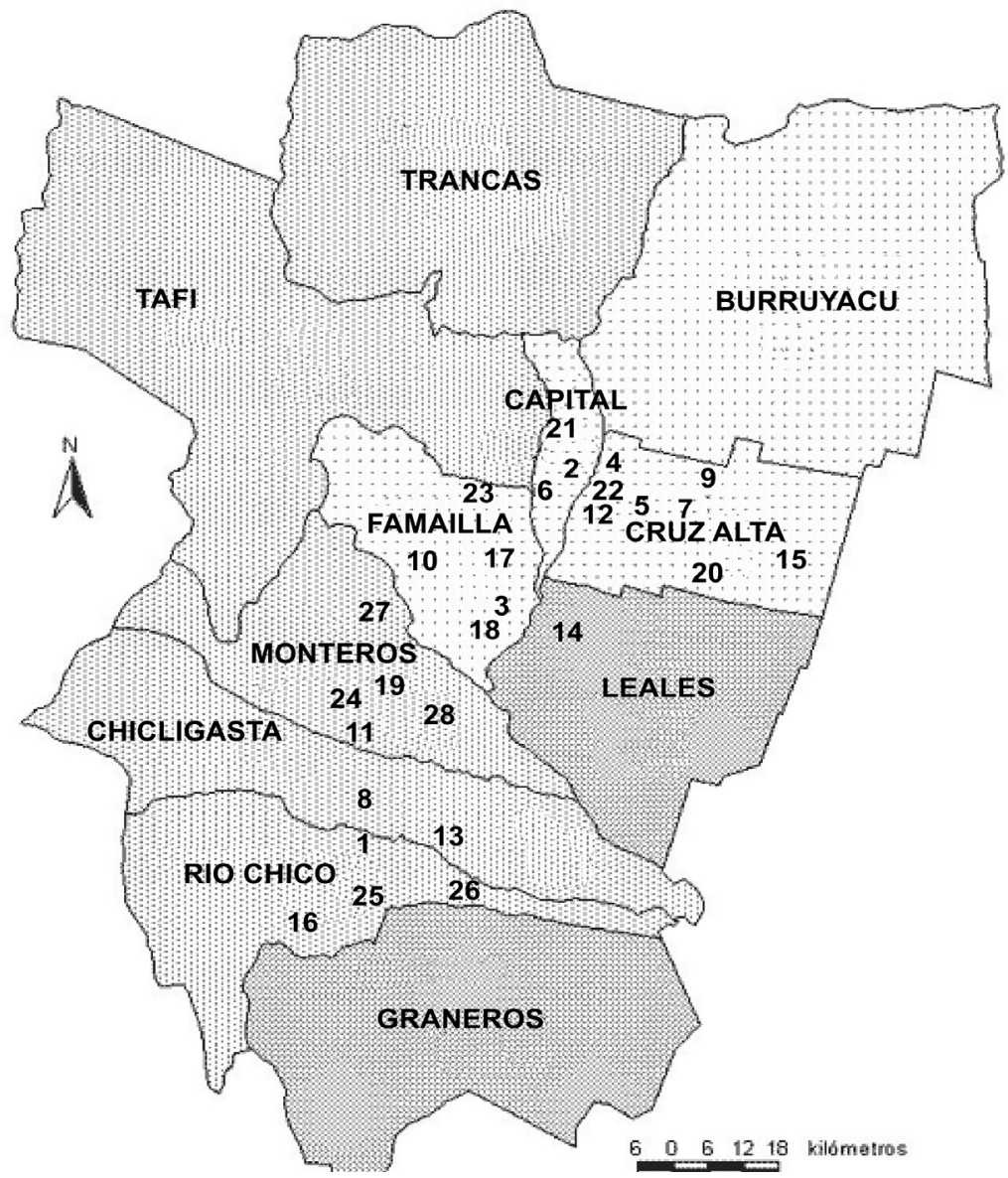

Referencias:

1. Aguilares, 2. Amalia, 3. Bella Vista, 4. Concepción, 5. Cruz Alta, 6. El Manantial, 7. Esperanza, 8. La Corona, 9. La Florida, 10. La Fronterita, 11. La Providencia, 12. Lastenia, 13. La Trinidad, 14. Leales, 15. Los Ralos, 16. Marapa, 17. Mercedes, 18. Nueva Baviera, 19. Nuñorco, 20. San Antonio, 21. San José, 22. San Juan, 23. San Pablo, 24. San Ramón, 25. Santa Ana, 26. Santa Bárbara, 27. Santa Lucía, 28. Santa Rosa.

Fuente: BCRA, INFORME DE LA COMISIÓN INTERMINISTERLAL DE ESTUDIOS AZUCAREROS, BCRA, BUENOS AIRES, 1949. 


\section{Bibliografía}

BALÁN, Jorge, "Migraciones, mano de obra y formación de un proletariado rural en Tucumán, Argentina, 1870-1914”, Demografía y economia, México, 1976, V. X, No 2, pp. 201-234.

BRAVO, María Celia, "Regulaciones en la Industria Azucarera Argentina, Estado, Cañeros e Industriales, 1928-1938”, en VIEIRA, Alberto (compilador) Historia do açúcar. Fiscalidade, Metrologia, Vida Material e Património, Centro de Estúdos do Atlántico, Funchal, 2006, pp. 124 - 152.

BRAVO, María Celia, Campesinos, azúcar y política: cañeros, acción corporativa y vida politica en Tucumán (1895-1930), Prohistoria Ediciones, Rosario, 2008.

BRAVO, María Celia, "Disputas sectoriales, agrarismo cañero y regulaciones en la industria azucarera tucumana en la década de 1930", en ASCOLANI, Adrián y OLIVERA, Gabriela (compiladores) Corporaciones y movimientos sociales agrarios en Argentina (1912-2008), Universidad Nacional de Rosario, Rosario, 2014.

BRAVO, María Celia y GUTIÉRREZ, Florencia, "La política azucarera argentina: de la concertación sectorial al tutelaje estatal (1928-1945”, en Revista H-industri@, Buenos Aires, 2014, No 14, pp. 153185.

CAMPI, Daniel: “Política azucarera argentina, 1945-1990: regulación y crisis” (inédito).

CAMPI, Daniel y KINDGARD, Adriana, "La política azucarera argentina en las décadas de 1920 y 1930 y la cuestión de la "justicia distributiva", ponencia presentada en III Congreso Brasileiro de Historia Económica, Curitiba, 1999.

GIRBAL-BLACHA, Noemí, "Cooperativismo agrario y crédito oficial (1946-1955). Una aproximación a las continuidades y cambios de la Argentina peronista”, en Anuario del Centro de Estudios Históricos "Prof. Carlos S. A. Segreti", Córdoba, 2001, Año 1, No 1, Disponible en: <http://www.cehsegreti.com.ar/ archivos/FILE_00000252_1310740130.pdf>

GIRBAL-BLACHA, Noemí, "El Estado benefactor, dirigista y planificador. Continuidad y cambio en la economía y la sociedad argentinas”, en GIRBAL-BLACHA, Noemí, ZARRILLI, Adrián y BALSA, Javier, Estado, Sociedad y Economía en la Argentina (1930-1997), Universidad Nacional de Quilmes, Bernal, 2001, pp. 69-108.

BUSTELO, Julieta, "Políticas azucareras durante el primer peronismo (1943-1955): cambios, continuidades y respuestas sectoriales”, en Travesía, San Miguel de Tucumán, 2015, V. XVIII, No 2, pp. 7-31.

BUSTELO, Julieta, "El nuevo asociacionismo de los cañeros tucumanos en los orígenes del peronismo: la formación de la Unión de Cañeros Independientes de Tucumán”, en Mundo agrario, La Plata, 2012, V. XVIII, No 25. Disponible en <http://mundoagrarioold.fahce.unlp.edu.ar>

BUSTELO, Julieta, "Hacia una caracterización de la estructura agraria cañera de Tucumán en los inicios del primer peronismo", en Revista del Departamento de Geografia, San Miguel de Tucumán, 2013-2014, No 14, pp. 9-28.

BUSTELO, Julieta, Asociacionismo cañero tucumano y politica azucarera durante el primer peronismo, Tesis Doctoral, Universidad Nacional de Tucumán, 2015. 
GIRBAL-BLACHA, Noemí, “Economía azucarera tucumana, empresarios y crédito en tiempos del Estado peronista (1946-1955)”, en MACOR, Darío y TCACH, César (editores) La invención del peronismo en el interior del país, Universidad Nacional del Litoral, Santa Fe, 2003.

GIRBAL-BLACHA, Noemí, "El crédito oficial al agro y a las industrias tradicionales. Estudio de casos" en GIRBAL-BLACHA, Noemí, Mitos, paradojas y realidades en la Argentina peronista (1046-1955), Universidad Nacional de Quilmes, Bernal, 2011.

GONZÁLEZ BOLLO, Hernán, "La Dirección Nacional de Investigaciones, Estadística y Censos y el estado peronista (1946-1949)”, en Estudos e pesquisas, Salvador, 2011, No 90, pp. 205-223.

LEÓN, Carlos, "El desarrollo agrario de Tucumán en el período de la transición de la economía de capitalismo incipiente a la expansión azucarera”, en Desarrollo Económico, Buenos Aires, 1993, V. XXXIII, No 130.

MURMIS, Miguel y WAISMAN, Carlos, "Monoproducción agroindustrial, crisis y clase obrera, la industria azucarera tucumana”, en Revista Latinoamericana de Sociología, Buenos Aires, 1969, V.V, No 2, pp. 344-383.

PUCCI, Roberto, “La élite azucarera y la formación del sector cañero en Tucumán (1880-1920)”, en Conflictos y Procesos de la Historia Argentina Contemporánea CEAL, Buenos Aires, 1989, No 37.

RUBINSTEIN, Gustavo, Los sindicatos azucareros en los orígenes del peronismo tucumano, Universidad Nacional de Tucumán, San Miguel de Tucumán, 2006.

SCHLEH, Emilio, La industria azucarera en su primer centenario, 1821-1921, Ferrari, Buenos Aires, 1921.

SCHLEH, Emilio, Compilación Legal sobre el Azúcar. Legislación de Tucumán, T. IV, Ferrari, Buenos Aires, 1939.

SCHLEH, Emilio, Compilación legal sobre el azúcar, T. XI, Ferrari, Buenos Aires, 1947. 